\title{
Improved production efficiency in cattle to reduce their carbon footprint for beef production
}

\author{
M.M. Scholtz ${ }^{1,2 \#}$, Y.Steyn ${ }^{3}$, E. van Marle-Köster ${ }^{3}$ \& H.E. Theron ${ }^{1}$ \\ ${ }^{1}$ ARC-Animal Production Institute, Private Bag X2, Irene, 0062, South Africa; \\ ${ }^{2}$ University of the Free State, PO Box 339, Bloemfontein, 9300, South Africa; \\ ${ }^{3}$ Department of Animal and Wildlife Sciences, University of Pretoria, Pretoria, 0002, South Africa
}

Copyright resides with the authors in terms of the Creative Commons Attribution 2.5 South African Licence.

See: http://creativecommons.org/licenses/by/2.5/za/

Condition of use: The user may copy, distribute, transmit and adapt the work, but must recognise the authors and the South African Journal of Animal Science

\begin{abstract}
The FAO publication, Livestock's Long Shadow, indicated that livestock is responsible for $18 \%$ of the world's greenhouse gas production thereby creating the perception that livestock is a major cause of global warming. Methane $\left(\mathrm{CH}_{4}\right)$ makes up $16 \%$ of total world gas emissions and is the second most important greenhouse gas $(\mathrm{GHG})$ after carbon dioxide $\left(\mathrm{CO}_{2}\right)$. Ruminants are important to mankind since most of the world's vegetation biomass is rich in fibre and only ruminants can convert this vegetation into high quality protein sources for human consumption. In spite of this important role of livestock, it is singled out as producing large quantities of GHG that contribute to climate change, since enteric fermentation is responsible for $28 \%$ of global $\mathrm{CH}_{4}$ emissions. However, the net effect from livestock is only a $4.5 \%$ contribution to GHG. The livestock industry should be aware of the effect of livestock on climate change and therefore it is important that mechanisms are put in place to mitigate this effect. The improvement of production efficiency through increased production per constant unit, crossbreeding and genetic improvement may be a cost effective and permanent way of reducing the carbon footprint of beef cattle.
\end{abstract}

Keywords: Methane, global warming, greenhouse gas, crossbreeding, residual feed intake, feed efficiency

\#Corresponding author: gscholtz@arc.agric.za

\section{Introduction}

Since 1980, scientific evidence of human interference on the climate placed the question of climate change and its environmental consequences on the world's political agenda. After various discussions, the Kyoto Protocol, adopted in December 1997 in Japan, officially established goals for emission of greenhouse gas (GHG) for industrialized nations (UNFCCC, 2007). This was followed by the United Nations Climate Change Conference in December 2009, known as the Copenhagen Summit, where a framework for climate change mitigation beyond 2012 was developed. The document recognized that climate change is one of the greatest challenges and that actions should be taken to keep global temperature increases as a result of GHG's to below $2^{\circ} \mathrm{C}$ by the end of the century. However, the document was not accepted unanimously.

It is estimated that more than $60 \%$ of global methane emissions are related to human activities (IPCC, 2007) and that enteric fermentation is responsible for $28 \%$ of global methane emissions. Human-related activities producing methane include fossil fuel production, animal husbandry (enteric fermentation in livestock and manure management), rice cultivation, biomass burning, and waste management. Natural sources of methane include wetlands, gas hydrates, permafrost, termites, oceans, freshwater bodies, nonwetland soils, wild ruminants (game) and other sources such as wild fires. The Food and Agricultural Organization (FAO) of the United Nations published Livestock's Long Shadow (Steinfeld et al., 2006), in which ruminants are accused of producing $18 \%$ of the greenhouse gas that cause global warming, thereby creating the perception that livestock is a major cause of global warming. From all methane emission sources, agriculture is by far the most important source in South Africa. Enteric fermentation in ruminants accounts for $90 \%$ of the agricultural sector's methane emissions (Blignaut et al., 2005). It is important to 
note, though, that if enteric fermentation is responsible for $28 \%$ of global methane emissions, and methane makes up $16 \%$ of total world GHG emissions, the net contribution of enteric fermentation to GHG's is only $4.5 \%(28 \%$ of $16 \%=4.5 \%)$.

Some studies have shown that the exclusive use of tanninferous legumes, or in combination with grasses in pastures for ruminant feeds, may reduce enteric methane emissions per unit of dry matter consumed $\left(\mathrm{g} \mathrm{CH}_{4} / \mathrm{Kg} \mathrm{DMC}\right)$ without affecting production performance (Pinares-Patino et al., 2003). Most research has focused on manipulating animal diet in an effort to inhibit a rumen environment favourable for methane production. Other options to combat enteric fermentation, such as genetic engineering and the use of additives, may be options (Beauchemin et al., 2008), but need further research.

The aim of this paper is to describe possible breeding technologies by which production efficiency in cattle can be improved in an attempt to reduce the carbon footprint of beef. These technologies include improved production per constant unit, crossbreeding and selection for residual feed intake.

\section{Discussion}

In ruminants, methane is produced by a specific group of bacteria, called methanogens (Moss, 1993), and protozoas, which may account for up to $20 \%$ of methanogenic microorganisms. As methane cannot be metabolized by the animal or microorganisms, it is partly absorbed by the ruminal wall and enters in the bloodstream where it is removed from the body during respiration or by eructation with carbon dioxide $\left(\mathrm{CO}_{2}\right)$ (Kozloski, 2002). Factors that influence enteric methane production in livestock are level of feed intake, diet composition, digestibility and quality of roughage, forage species, $\mathrm{C} 3$ versus $\mathrm{C} 4$ grasses, cultivar and variation between animals. From a nutritional point of view, methane represents a potential loss of energy by the animal of between 6 and $10 \%$; this is not converted to a product (meat, milk, wool).

Variations in methane production between animals, breeds, and across time have been reported and provide the potential for improvement through selection (Wall et al., 2009). Ways to improve efficiency through genetics include choice of breed, the use of crossbreeding and selection within breeds (Herd et al., 2003).

The emission of GHG from livestock is measured either in terms of $\mathrm{kg} \mathrm{CO}_{2}$ equivalent per $\mathrm{kg}$ of meat or milk available for consumption, or per area of land used. In the case of ruminants, extensive systems are usually found to have a lower per-area footprint than intensive grain-fed systems, but a higher footprint if expressed in terms of $\mathrm{kg} /$ product (Garnett, 2010). Improved production per unit can thus reduce the carbon footprint of beef.

\section{Improved production per constant unit}

Most measurements for beef improvement in South Africa and the world are expressed per individual, for example weaning weight, calving interval and average daily gain (ADG). Although breeding values are estimated for traits such as feedlot profit and cow efficiency in the Bonsmara, breeding values are still only estimated once or twice a year. Until breeding values are estimated more frequently and breeding values for cow efficiency for all breeds are available in South Africa, farmers will need a measurement that can be available immediately (as is the case with weaning weight) after measurement that can be used in selection. It is therefore essential that a measurement is developed that can express performance in a per constant unit base, e. g. kg calf weaned per Large Stock Unit. It should also be investigated whether it will be possible to convert such a measure into $\mathrm{kg}$ calf produced per $\mathrm{kg} \mathrm{CO}$ equivalent $\left(\mathrm{CH}_{4}\right.$ can be converted to a $\mathrm{CO}_{2}$ equivalent) by adjusting it for half-life and heating potential.

\section{Crossbreeding}

The advantages of terminal crossbreeding to improve efficiency do not lie in the higher growth rates or better feed conversion ratio (FCR) of the crossbred progeny per se, but rather depends on the extent to which the weight of the slaughter animal can be increased relative to that of the dam or breeding cow. This advantage follows since any system with large slaughter animals from small breeding cows must be more efficient than one with slaughter animals and breeding animals of equivalent size, simply because small dams eat less than large ones. Another advantage of crossbreeding arises from a potential increase in weaning weight of up to $26 \%$ per cow exposed to mating, while the feed energy requirement only increases by 1\% (MacNeil, 2005; MacNeil et al., 1991; MacNeil et al., 2007). 
Maternal heterosis is also of major importance in reproductive traits, making crossbred dams desirable in crossbreeding systems. Cundiff et al. (1974) obtained 14.8\% more calf weight per cow exposed in crossbred cows compared to purebred cows, both producing crossbred calves with equal individual heterozygosity and additive genetic composition, illustrating the importance of the crossbred dam. Miller (2010) claims that heterosis in a sound crossbreeding programme can increase productivity in the beef cow herd by $20 \%$ to $25 \%$ over a comparable straight breeding programme.

\section{Residual feed intake}

A possible trait to improve production through selection within breeds is residual feed intake (RFI). In beef cattle, the concept RFI, also referred to as net feed intake, was proposed by Koch et al. (1963) and is defined as the difference between actual and predicted feed intake required for the observed rate of gain and body weight. A low RFI value indicates a more efficient animal and many studies have found heritability estimates varying from 0.28 to 0.58 (e.g. Crews et al., 2003). Possible genetic markers for RFI have been investigated but the success rate has been low (Moore et al., 2009).

In selection for low RFI animals, methane production and energy lost as methane was $28 \%$ lower in low RFI steers compared to high RFI steers, resulting in approximately 16100 litres less methane produced per year from such steers (Nkrumah et al., 2006). In another study a $13.38 \mathrm{~g} / \mathrm{d}$ reduction in methane emission was associated with a $1 \mathrm{~kg} / \mathrm{d}$ reduction in an EBV for RFI and low RFI steers emitted $25 \%$ less methane daily (Hegarty et al., 2007). The difference in methane production in high and low RFI animals cannot be explained by the difference in feed intake alone. Possible reasons could be differences in metabolism and possible individual animal differences in methane production (Nkrumah et al., 2006). There seems to be a genetic component influencing the types of methanogenic bacteria present and their hosts (Hackstein et al., 1996).

The common measure of efficiency is feed conversion ratio (FCR). However, FCR is highly associated with growth rate (Koots et al., 1994), leading to an increase in mature size, which in turn increases the maintenance cost of the breeding herd (Liu et al., 2000). It has been shown that RFI is independent from mature weight and ADG, while being highly correlated to feed intake and FCR, leading to the reduction of feed intake without affecting growth performance or cow size (Nkrumah et al., 2007). Studies have shown that low RFI cattle have less whole-body chemical fat and more whole-body chemical protein than high RFI cattle (Richardson et al., 2001). Even with the decrease in body fat, low RFI animals still meet market specifications in respect of fat content for feedlot animals (Nkrumah et al., 2004).

\section{Conclusion}

Ruminants are important to mankind since most of the world's vegetation biomass is rich in fibre. Only herbivores can convert this fibre-rich vegetation into high quality protein sources for human consumption. In spite of this important role of livestock, it is specifically being singled out as producing large quantities of GHG that contribute to climate change. The popular press is fuelling these sentiments with slogans telling consumers to eat less meat. It is therefore important that the livestock industry should recognise the potential negative effects of livestock on climate change. It is also important that mechanisms are put in place to mitigate this effect, and since genetic improvement is permanent, it may be a cost effective approach.

\section{References}

Beauchemin, K.A., Kreuzer, M., O'Mara, F. \& McAllister, T. A., 2008. Nutritional management for enteric methane abatement: A review. Aust. J. Experimental Agric. 48, $21-27$.

Blignaut, J.N., Chitiga-Mabugu, M.R. \& Mabugu, R.M., 2005. Constructing a greenhouse gas inventory using energy balances: the case of South Africa for 1998. J. Energy S. Afr. 16, 21-32.

Crews Jr., D.H., Shannon, N.H., Genswein, B.M.A., Crews, R.E., Johnson, C.M. \& Kendrick, B.A., 2003. Genetic parameters for net feed efficiency of beef cattle measured during post-weaning growing versus finishing periods. Proc. West. Sect. Amer.. Soc. Anim. Sci. 54, 125-128.

Cundiff, L.V., Gregory, K.E., Schwulst, F.J. \& Koch, R.M., 1974. Effects of heterosis on maternal performance and milk production in Hereford, Angus and Short Horn cattle. J. Anim. Sci. 38, 728745 . 
Garnett, T., 2010. Intensive versus extensive livestock systems and greenhouse gas emissions. Food Climate Research Network briefing paper. January 2010.

Hackstein, J.H.P., Langer, P. \& Rosenberg, J., 1996. Genetic and evolutionary constraints for the symbiosis between animals and methanogenic bacteria. Environ. Monit. Assess. 42, 39-56.

Hegarty, R.S., Goopy, J.P., Herd, R.M. \& McCorkell, B., 2007. Cattle selected for lower residual feed intake have reduced daily methane production. J. Anim. Sci. 85, 1479-1486.

Herd, R.M., Archer, J.A. \& Arthur, P.F., 2003. Reducing the cost of beef production through genetic improvement in residual feed intake: Opportunity and challenges to application. J. Anim Sci. 81, 9-17.

IPCC, 2007. Climate Change 2007: The Physical Science Basis Contribution of Working Group I to the Fourth Assessment Report of the Intergovernmental Panel on Climate Change. In: Solomon, S., D. Qin, M. Manning, Z. Chen, M. Marquis, K.B. Averyt, M. Tignor and H.L. Miller (Eds.). Cambridge University Press, Cambridge, United Kingdom and New York, pp. 996.

Koch, R.M., Swiger, L.A., Chambers, D. \& Gregory, K.E., 1963. Efficiency of feed use in beef cattle. J. Anim. Sci. 22, 486-494.

Koots, K.R., Gibson, J.P. \& Wilton, J.W., 1994. Analyses of published genetic parameter estimates for beef production traits. 2. Phenotypic and genetic correlations. Anim. Breed. Abst. 62, 825-853.

Kozloski, G.V., 2002. Bioquímica dos ruminantes. Santa Maria: Editora UFSM, p. 140.

Liu, M.F., Goonewardene, L.A., Bailey, D.R.C., Basarab, J.A., Kemp, R.A., Arthur, P.F., Okine, E.K. \& Makarechian, M., 2000. A study on the variation of feed efficiency in station tested beef bulls. Can. J. Anim. Sci. 80, 435-441.

MacNeil, M.D., 2005. Beef Cattle Management: Crossbreeding. In: Encyclopedia of Animal Science. Marcel Dekker, New York, NY.

MacNeil, M.D. \& Newman, S., 1991. Using heterosis to increase profit. Proc. Int. Beef Symp. Great Falls, Montana, 129-134.

MacNeil, M.D. \& Matjuda, L.E., 2007. Breeding objectives for Angus and Charolais specialized sire lines for use in the emerging sector of South African beef production. S. Afr. J. Anim. Sci. 37, 1-10.

Miller, S.P., 2010. Fact sheet: Crossbreeding systems for beef production. Available at: www.omafra.gov.on.ca/enghlish/livestock/beef/crossbreeding

Moore, S.S., Mujibi, F.D. \& Sherman, E.L., 2009. Molecular basis for residual feed intake in beef cattle. J. Anim. Sci. 87, 41-47.

Moss, R.A., 1993. Methane: Global warming and production by animals: Chalcombe Publications, Canterbury. p. 105.

Nkrumah, J.D., Basarab, J.A., Price, M.A., Okine, E.K., Ammoura, A., Guercia, S., Hansen, C., Li, C., Benkel, B., Murdoch, B. \& Moore, S.S., 2004. Different measures of energetic efficiency and their phenotypic relationship with growth, feed intake, and ultrasound and carcass merit in hybrid cattle. J. Anim. Sci. 82, 2451-2459.

Nkrumah, J.D., Okine, E.K., Mathison, G.W., Schmid, K., Li, C., Basarab, J.A., Price, M.A., Wang, Z. \& Moore, S.S., 2006. Relationship of residual feed intake and metabolic rate, methane production and energy partitioning in beef cattle. J. Anim. Sci. 84, 145-153.

Nkrumah, J.D., Sherman, E.L., Li., C., Marques, E., Crews Jr., D.H., Bartusiak, R., Murdoch, B., Wang, Z., Basarab, J.A. \& Moore, S.S., 2007. Primary genome scan to identify putative quantitative trait loci for feedlot growth rate, feed intake, and feed efficiency of beef cattle. J. Anim. Sci. 85, 3170-3181.

Pinares-Patiño, C.S., Ulyatt, M.J., Waghorn, G.C., Lassey, K.R., Barry, T.N., Holmes, C.W. \& Johnson, D.E., 2003. Methane emission by alpaca and sheep fed on lucerne hay or grazed on pastures of perennial ryegrass/white clover or birdsfoot trefoil. J. Anim. Sci. 140, 215-226.

Richardson, E.C., Herd, R.M., Oddy, V.H., Thompson, J.M., Archer, J.A. \& Arthur, P.F., 2001. Body composition and implications for heat production of Angus steer progeny of parents selected for and against residual feed intake. Aust. J. of Experimental Agric. 41, 1065-1072.

Steinfeld, H., Gerber, P., Wassenaar, T., Castel, V., Rosales, M. \& de Haan, C., 2006. Livestock's long shadow: Environmental issues and options. Rome, FAO, pp 390.

UNFCCC, 2007. United Nation Framework Convention on Climate Change. Available at: http://unfccc.int/kyoto_protocol/items/2830.php.

Wall, E., Simm, G. \& Moran, D., 2009. Developing breeding schemes to assist mitigation of greenhouse gas emissions. Anim. 4, 366-376. 